\title{
Teaching Technique of Islamic Studies in Higher Learning Institutions for Non-Arabic Speakers: Experience of Faculty of Quranic and Sunnah Studies and Tamhidi Centre, Universiti Sains Islam Malaysia
}

\author{
Azniwati Abdul Aziz", Mohamed Akhiruddin Ibrahim, Mohammad Hikmat Shaker, Azlina Mohamed Nor
}

Tamhidi Centre, Universiti Sains Islam Malaysia, Malaysia

Copyright $\subseteq 2016$ by authors, all rights reserved. Authors agree that this article remains permanently open access under the terms of the Creative Commons Attribution License 4.0 International License

\begin{abstract}
Globalization causes educational institutions to encounter various challenges and demand, in which they need to play their roles in improving competitiveness and world-class quality education. Universiti Sains Islam Malaysia (USIM) as a university that integrates Naqli and Aqli knowledge has taken the globalization challenge by requiring the adoption of English and Arabic language as a teaching and learning medium with adaptability of knowledge discipline even though majority of the lecturer and students are non-speakers of those languages. For Islamic Studies field, the required medium is Arabic language since it is a discipline of al-Naqli knowledge which is based on knowledge in Arabic language where all the basic sources of Islamic studies namely al-Quran, Hadis and Thurath books are in Arabic language. The objective of this article is to study the teaching techniques applied by the non-Arabic speaking lecturers when they carry out teaching and learning process of Islamic studies to non-Arabic speaking students. This research was conducted based on experience of the lecturers of Islamic studies at Faculty of Quranic \& Sunnah Studies and Tamhidi Centre, USIM. From the research, it was found that each teaching method such as lecture session, tutorial and e-learning was conducted with different teaching techniques. Various techniques have been applied accordingly such as brainstorming, discussion, presentation, story-telling, role play, Q\&A, quiz, forum, and exercises. Result shows that the teaching techniques applied in teaching Islamic studies for non-Arabic speakers are suitable with the ability and basic knowledge of students. Result also found that the techniques used are significance in teaching process for non-Arabic speaking students in higher education level. Since the students of Faculty of Quranic \& Sunnah Studies and Tamhidi Centre have basic knowledge in Arabic language and Islamic studies while they were in high school, research suggests on pursuing these teaching techniques and enhancing them from time to time.
\end{abstract}

Keywords Teaching Method, Islamic Studies, Non-Arabic Speaker, Higher Education

\section{Introduction}

Delivery of quality teaching emphasizes on coherent presentation, sequential materials, adequate opportunities for student involvement in integrated training, the use of regular and periodic measurements and constructive feedback to students (Muhamad Suhaimi Taat et al., 2012, p.B4). The use of effective methods and techniques should be used during the process of teaching and learning. Both must be consistent with the strategy and approach adopted. Although there are differences of purpose and function among strategy, approach, method and technique, there is an interrelated relationship among them, as described in the following figure (Teacher Education Institute, 2011, p.11):

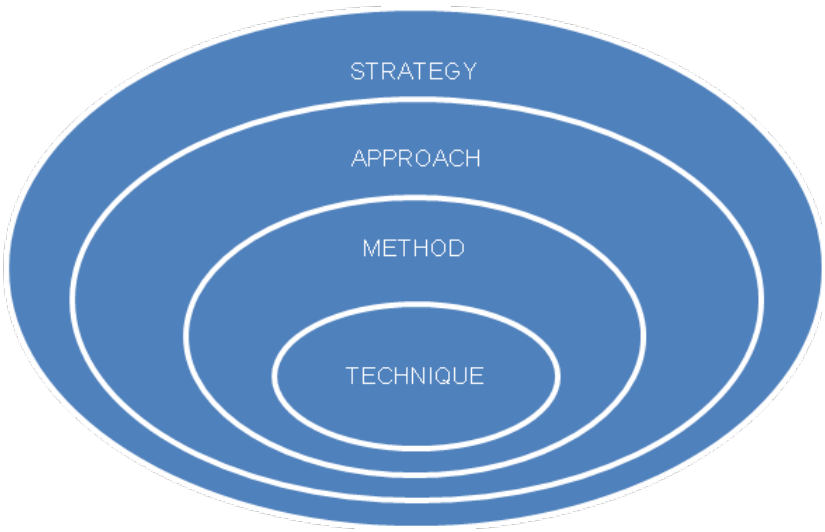

Figure 1. Relationship among strategy, approach, method and technique.

\subsection{Strategy}

Strategy is a concept that involves process of planning so 
as to determine actions that should be taken in achieving the intended goals. In teaching and learning context, strategy means ways or steps or actions that must be implemented in order to achieve the objectives of teaching and learning. Strategy therefore, focuses on achievement or learning outcomes (Teacher Education Institute, 2011, p.11).

\subsection{Approach}

There are various types of approaches which are Inductive Approach, Deductive Approach, Eclectic Approach, Communicative Approach, Interactional Approach and Integrated Approach (Teacher Education Institute, 2011, p.13). According to Parera (1986), approach is the background of philosophy or opinion about main idea to be debated and is an axiom that is generally accepted statement form the basis of a description (Chang Lee Hoon, p.17). Approach is also a way to deal with a subject, namely how a subject can be taught based on its objectives, and hence, it becomes a systematic set of theory (Mok Soon Sang, 1992).

\subsection{Method}

Method is a systematic series of actions to achieve the objectives of the learning outcomes in short term. Teaching method is a way to accomplish a learning objective through organized presentation delivery (Mok Soon Sang, 1992). It also means moving towards a learning objective which has been planned and organized (Sharifah Alwiah, 1986). Method is also a means to achieve a goal; therefore, whatever ways that teachers do to make the students understand so as to achieve the teaching objectives, then it is a method (Hasan Langgulung, 1981). Definition of method is also described as a teaching activity that consists of organized steps, and in each step, there is a planned skill and practice. Teaching method is not the main purpose of teaching, but it is a wasilah, that is a way to achieve teaching objective (Abu Saleh, 1988).

This therefore means that teaching method is a plan or procedure adopted to implement teaching in an orderly, organized and systematic manner. Method is an organized, continuous teaching step that is structured and should be implemented in order to accomplish a teaching objective. Among the methods proposed for use in teaching and learning are natural method, grammar translation method, direct method, Hafaz method, linguistic method, code-cognitive method, oral-aural method, natural method, soldier method, psychological method and specific method (Teacher Education Institute, 2011, p.12).

\subsection{Technique}

According to Edward M. Anthony, technique is a trick or strategy or tactics used by teachers to achieve maximum results immediately in teaching a specific part of a language. In general, technique is what is seen in the classroom (Azman Wan Chik, 1987) that is teacher's skills in the management and implementation of teaching methods in teaching and learning activities. If a teacher teaches language using advanced communication tools in a language laboratory, then it's a technique (Muhammad Azhar et al., 2012, p.894). If an Islamic Education teacher teaches a student to memorize al-Quran by listening to the recitation in cassette, then it is a technique. In conclusion, technique is a control of an organization that really happens in classrooms where it is used to achieve an objective. There are various types of technique namely role-play, games, drill, storytelling, discussion, debate, quizzes, brainstorming, question and answer, simulation, drama and inquiry techniques (Abdul Rasidet al., 2013, pp.47-49).

Based on the definitions described above, it can be generally understood that strategies the planning of teaching such as teacher-centered, student-centered, and material-centered. Approach is a way to deal with a subject that is how a subject is taught according to its objectives. In addition, method is a systematic series of actions to achieve the learning objectives in a short term. Teaching method is a way to approach a learning objective through structured delivery. Technique, on the other hand, is a teacher's skill in managing and implementing a teaching and learning activity (Muhamad Suhaimi Taat et al., 2012, p.B4).

\section{Background of Studies in the Faculty of Quranic and Sunnah Studies (Fpqs) and in Tamhidi Centre, Islamic Science University of Malaysia (Usim)}

\subsection{Faculty of Quranic and Sunnah Studies (FPQS)}

The objective of the establishment of FPQS is to uphold the Quran and Sunnah studies in mainstream education by emphasizing the use of information technology in its teaching and research. In addition, it also seeks to expand Islamic beliefs by providing more opportunities for researchers and educators to study, research and disseminate knowledge and wisdom contained in the holy book of Quran and Sunnah to the society and country (Academic Division, 2005, p.18).

In order to ensure that these goals are accomplished, FPQS has established three programs, namely Bachelor of Quranic and Sunnah Studies with Honours, Bachelor of Quranic Studies with Multimedia with Honors and Bachelor of Sunnah Studies with Information Management with Honours (Kandil et.al., 2007, p.78).

\subsection{Tamhidi Centre, Islamic Science University of Malaysia (USIM)}

USIM Tamhidi Programme is a programme for SPM leavers that prepare them for their First Degree. Tamhidi is an Arabic word which means 'Setup' which is similar to the terms 'Matriculation' in the Ministry of Education and the 
International Islamic University Malaysia, 'Foundation' at the University of Malaya, 'Foundation Year' at Universiti Teknologi Malaysia or similar to the pre-university programme (STPM , HSC or A 'Level). Therefore Tamhidi Programme is equivalent to 'foundation' or fundamental programs conducted by the above-said universities. There are 5 Tamhidi programmes offered, namely Tamhidi of Medicine, Tamhidi of Science and Technology, Tamhidi of Syariah and Law, Tamhidi of Accounting and Muamalat and Tamhidi of Dentistry (http://tamhidi.usim.edu.my/).

An essential prerequisite for entrance into any academic center or faculty in USIM is passed Arabic subjects in SPM (Tamhdi Centre, 2005, p. 9). Students who do not have any basics in Arabic language are not eligible to apply since the teaching and learning system in USIM is using English and Arabic only as a medium of instruction. Arabic language courses are compulsory university courses that must be learned by all students from all fields of specialization.

\subsection{Position of Islamic Studies at the Faculty of Quran and Sunnah (FPQS) and in Tamhidi Centre}

The vision of FPQS is to uphold al-Quran and Sunnah in producing man that is based on Islamic education and recent technology that is able to contribute to the society, nation and the whole world (Academic Division, 2005, p.19). Therefore, the courses of Islamic studies are the basic or main courses for all programmes offered.

Unlike FPQS, only one of the five programmes offered by Tamhidi Centre requires Islamic studies course as the main course namely Tamhidi of Syariah and Law programme. However, to realize the objectives of the university that is committed to producing Muslim professional graduates who not only have expertise in the field of Medical Sciences, Science, Technology, Engineering, Economics, Accounting, and Muamalat Syariah and Law, but also possess good ethics and proper understanding about Islam without neglecting other programmes (Academic Division, 2005, p.13). Tamhidi Centre has provided Islamic studies courses as compulsory courses that are relevant and significant to the five programs offered. Similar to the practice in FPQS, the teaching and learning, learning modules and reference books for all courses of Islamic studies courses are in Arabic.

Since the establishment of USIM until now, all the lecturers and students of Islamic studies courses in Tamhidi Centre are non-Arabic speakers. However, just like the scenario in FPQS, the lecturers are able to speak in Arabic as they used to further their education in countries like Jordan, Egypt, and Morocco. On the other hand, the students have the basic skills to understand and speak in Arabic as they learnt Arabic in secondary school that makes it as a compulsory subject.

\section{Methods and Techniques of Teaching Islamic Studies}

According to Zahiah Haris (2011), in order to ensure the teaching and learning process can be implemented effectively and meet the objectives set, these are the rules recommended by the Division of Teacher Education for each field in Islamic Education, namely: First, Field of Al-Quran Recitation and Memorization. The proposed methods for this field are talaqqi musyafahah, tikrar, hafazan, and tasmi'. Second, Field of Aqidah. Under this particular field, the proposed techniques are discussion, workshops, brainstorming, reflection, and teaching with computer. Third, Field of Ibadah. For this field, the proposed methods are discussion, brainstorming, practical, simulation, collaboration, and co-operative learning. Fourth, Field of Akhlak and Morality. The suggested teaching techniques under this field are lectures, discussions, simulations, forum, future studies, contextual teaching, reflection, and group activities.

According to a study done by Ab. Halim Tamuri (2010), question and answer technique, demonstration, memorization, drills and lectures are techniques commonly used by teachers when teaching. In addition, based on a study conducted by Kamarul Azmi Jasmi (2011), generally the majority of outstanding teachers of Islamic education are using questionnaires, group discussions, student-teacher discussions, reciting verses from the Quran, demonstrations, motivation, memorizing individually, memorizing in groups and practice in their teaching. However, storytelling and brainstorming techniques are used more frequently by excellent Islamic Education teachers in urban areas.

Generally, the course delivery methods in higher education are in the forms of lectures, tutorials, and e-learning as well as individual or group assignments, discussions and presentations (Course Outline, Tamhidi Centre, 2013). It is very apparent that educators will apply and implement various teaching techniques during lecture or tutorial in order to ensure the teaching objectives are met. Hence, the primary challenge for Islamic studies courses in USIM is when the lecturers need to deal with students who are not native speakers of Arabic and in general do not have the experience of studying with full Arabic language medium in schools. Students' ability to understand the content of lessons in Arabic during lecture is the main objective of each lesson, but the lecturer cannot and should not simply translate the content into Bahasa Malaysia or English. This definitely violates teaching ethics in USIM.

\subsection{Question-answer Technique}

Lecturing is a common method frequently used by majority of lecturers in which one-way teaching takes place. In order to reinforce this technique, lecturer should give about ten to twenty minutes for the students to ask questions after the lecture has ended (Zahiah Haris@Harith \& Mustapha Kamal Ahmad Kassim, 2011, p. 286).

This technique is also implemented through the lecturer asking questions relating to the subject matter and students need to respond accordingly. Questions are raised after the 
completion of briefing sessions for each sub-topic. This technique is intended to detect the level of understanding of students, encourage students to explain information clearly as well as to assess the ability to speak in Arabic. This technique will be more effective when planned and quality questions are asked as it can help sharpen students' thinking skills while creating a more dynamic and efficient learning environment.

\subsection{Role-play Technique}

This technique is usually used spontaneously by the lecturers. When majority of students cannot understand the situation explained, the lecturer will ask some of the students who are able to understand it well to dramatize it. This technique is a form of drama that does not require scripts memorization and the lecturer will only act as a facilitator before the play starts. Students who act in this technique will try to explain a situation to other students through acting and language styles that can be understood easily among them.

Simulation method is a controlled learning situation and deliberately created in which it simulates the real situation with the aim of training to solve a problem. There are two types of methods, namely sociodrama and role-play. Sociodrama is acting activities based upon a story. On the other hand, role-play is acting spontaneously involving a group of students (Zahiah Haris@ Harith \& Mustapha Kamal Ahmad Kassim, 2011, p. 286), Not only is this technique able to turn a very positive learning environment, but also it can build positive qualities in students. Habit of helping others to understand the lesson content can be fostered indirectly by using this technique.

\subsection{Story-telling Technique}

One purpose of this technique is to give simple examples of the subject content which can be understood easily and remembered well by the students. Most lecturers use appropriate personal experiences and present it in a simple, easy and effortless language style. Good intonation and body language help students to better understand the story and its relationship with the teaching content.

A study conducted by Maimun Aqsa Lubis (2005) showed techniques of storytelling and acting are among effective techniques for students to think in an Islamic way, which can encourage their interest to learn Islamic knowledge, help them practice Islamic teachings, improve their moral and attitude, assist them in assessing and improving their character, building their sense of responsibility towards themselves, their families and communities as well as help them to be good. An appropriate story that is told in an interesting style makes it a technique that can attract students' attention and concentration in teaching and learning process. (Ee Ah Meng, 1993).

\subsection{Drilling Technique}

Lecturers apply drilling technique when they have to repeat the facts learned repetitively. It aims to achieve a skill such as pronunciation skills, or to make the students remember and memorize important facts. Through this technique, students need to be alert as they need to listen, see and think about the meaning of the words according to context.

According to the Division of Teacher Education, it is known as tikrar technique that is suggested for the Quranic recitation and memorization, whereby the lecturers ask the students to read the Quran repetitively so that it can be remembered easily (Zahiah Haris @ Harith \& Mustapha Kamal Ahmad Kassim, 2011, p. 284). It is also suitable to be applied by the author as most Arabic words have more than one meaning.

\subsection{Discussion Technique}

This technique is usually made in tutorial classes. The purpose is to train students to express themselves excellently. The lecturer divides the students into groups; assigns each group to discuss among themselves while being monitored so that the discussion is focused. After the discussion period ends, the lecturer will ask for a report from each group. The lecturer will encourage the students to present in a form of speech, not through reading out loud. Indirectly, this can enhance the students' ability to speak in Arabic with the correct use of language. Some lecturers use e-learning to create forums with topics related to their subject matter. Lecturers will participate in that online forum to monitor any negative element in the discussion. In addition, they can also monitor the progress of students in writing Arabic language.

This is a very significant technique because it involves all students in the class and they play an active role in the discussion sessions. It aims to train students to express their thoughtful, logical and mature views within a defined time period, encourage students to collaborate and share ideas, create an interest to read as it is necessary for them to make references (Mak Soon Sang, 1993). Discussion technique is strongly encouraged by Imam As-Syafie since a problem could be discussed without any restrictions of giving an opinion as long as it does not contradict with the Islamic law (Ahmad Mohd Salleh, 2004).

\subsection{Brainstorming}

This technique can encourage broad, critical and creative thinking. One advantage of brainstorming compared to other techniques is that it is particularly suitable to train students in communication skills. In addition to learning how to present their views responsibly, students also learn to accept the views of others who may not be in line with theirs. Indirectly, this can widen the students' perspectives towards many things particularly to knowledge and student life (Maria Chong Abdullah etc., tt, p. 11). Effectiveness of brainstorming session depends on some situations, whereby 
lecturer shows a positive attitude as well as promotes positive thinking among pupils, students' active participation, unbiased lecturer that does not favor any individual or group and the chosen ideas should be used accordingly.

\section{Conclusion and Recommendation}

Based on the situation where the teaching and learning process is in Arabic language medium, and the teaching modules are also in Arabic, while the students are not native speakers of Arabic, it is recommended that the Islamic studies lecturers to be concerned with the student's level of mastering the language itself. This is because, based on the study of the correlation between the ability to speak Arabic with achievement of studying fiqh by Khairol Anwar (2010), it is found that in order to be able to learn the Islamic values well, it is required to have good and moderate Arabic language skills.

According to Khairol Anwar (2010), the indicators of Arabic skills are as follows:

1. Able to read, either reading out loud, in heart or analytically. Reading out loud is carried out with a loud voice and able to be understood by others. Reading in heart is to gain understanding and get important points. Meanwhile, reading analytically is to train students to search for information.

2. Able to write, either the information is able to be written well enough, or able to express opinions and feelings in a good piece of writing.

3. Able to listen, either in identifying hijaiyyah hurufs or phrases in matching and differentiating information, or obtaining general information accurately.

4. Able to speak, either to convey information orally with simple sentences, or make a simple dialogue well, or express opinions and feelings orally very well.

In conclusion, given the fact that students of Faculty of Qur'anic and Sunnah Studies and Tamhidi Centres have some basics in Arabic and Islamic Studies, the authors found out that the techniques implemented in teaching Islamic studies to non-native Arabic speakers were suitable and in accordance with students' ability and knowledge. It is also found that the techniques used are significant in the non-native Arabic speakers' learning process at higher learning institution. Hence, the authors recommend the teaching techniques to be practiced and improved from time to time.

\section{Closing}

No one strategy, approach, method or technique that works best for all courses for all students in all circumstances. It should be changed according to circumstances of time, place and students. According to Al-Kailany and Iyad, among the important guidelines before applying any method or technique of teaching in general, first, it must be commensurate with the goals and objectives of the lesson, second, it must be in line with the objectives intended to be achieved, third, it must be in accordance with the nature of the subjects taught, fourth, it must be suitable with the age of students; fifth, it can be applied by instructors to have enough time to implement it and finally, it is in accordance with the existing facility (Muhamad Suhaimi Taat et al., 2012, p.B4).

In addition, the teaching session will be successful with the selection of teaching methods and techniques that can have a profound impact not only on the understanding of students, but also affecting and touching their heart. In this way students will stay focus and be able to remember the lessons faster and better.

\section{REFERENCES}

[1] Abdul Rasid Jamian et al. ( 2013).Interaksi Lisan Dalam Pengajaran Dan Pembelajaran Bahasa Melayu (Verbal Interaction In Teaching And Learning Of Malay Language) Jurnal Pendidikan Bahasa Melayu - JPBM (Malay Language Education Journal - Mylej) Vol. 3, Number. 1 (Mei 2013): 42-51.

[2] Abu Saleh, Muhibuddin Ahmad. (1988). Asasiyat Fi Turuq At-Tadris Al-'Ammah. Riyadh: Dar al-Huda.

[3] Ab. Halim Tamuri, Mohamad Khairul Azman Ajuhary. (2010). Amalan Pengajaran Guru Pendidikan Islam Berkesan Berteraskan Konsep Muallim. Journal Of Islamic And Arabic Education 2(1), 43-56).

[4] Kamarul Azmi Jasmi, Ab. Halim Tamuri, Mohd Izham Mohd Hamzah. (2011). Kajian Kes Penggunaan Kaedah Pengajaran Dan Pembelajaran Guru Cemerlang Pendidikan Islam (GCPI) Sekolah Bandar Dan Luar Bandar : Satu Kajian Perbandingan. . Jurnal Teknologi, 56 (Sains Sosial), Sept. 2011: 179-198Penerbit UTM Press, Universiti Teknologi Malaysia.

[5] Haji Maimun Aqsha Lubis, Roslan Hj Aspar. (2005). Kaedah Pengajaran Pengetahuan Agama Islam Di Brunei Darussalam. Jurnal Pendidikan 30 (2005) 141-150.

[6] Khairol Anwar . (2010) Korelasi Antara Kemampuan Berbahasa Arab Dengan Prestasi Belajar Fiqih Siswa Kelas Xii MA Ali Maksum Pondok Pesantren Krapyak Yogyakarta.

[7]Zahiah Haris@ @arith, Mustapha Kamal Ahmad Kassim. (2011). Pendidikan Islam Kursus Perguruan Lepas Ijazah Di Institut Pendidikan Guru Malaysia: Kaedah Dan Proses Pengajaran Dan Pembelajaran Yang Berkesan Atikan, 1(2).

[8] Maria Chong Abdullah, Samsilah Roslan Dan Tajularipin Sulaiman. (T.T). Strategi Pengajaran Pembelajaran Di Institusi Pengajian Tinggi: Satu Anjakan Paradigma. Fakulti Pengajian Pendidikan Universiti Putra Malaysia, Selangor.

[9] Academic Division. (2005). Buku Panduan 2005/2006 Fakulti Pengajian Quran dan Sunnah. Bandar BaruNilai: 
Penerbit USIM.

[10] Al-Kailany, Taisir and Iyad, Mulhim.(1986). At-Taujih Al-Fanny Fi Usul al-Tarbiyah Wat-Tadris. Beirut: MaktabahLubnan.

[11] An-Nashmy, Ajil Jasim. (1980). Ma`Alim Fit-Tarbiyah.Kuwait: Maktabah al-Manar.

[12] Azman Wan Chik. (1987). KaedahHayatiAmali. Kuala Lumpur: KaryaBistari.

[13] Chang Lee Hoon. Pendekatan Dalam Pendidikan Moral, Fakulti Pendidikan, Universiti Malaya. An article in $\mathrm{http}: / /$ www.academia.edu.

[14] Faculty of Quranic \& Sunnah Studies. (2014). Course Outline of Faculty of Quranic \& Sunnah Studies. Universiti Sains Islam Malaysia.

[15] Faculty of Quranic and Sunnah Studies. Universiti Sains Islam Malaysia. http://fpqs.usim.edu.my. 29 October 2014.

[16] Hadijah binti kodiron. (2010). Komponen Penyampaian Yang Perlu diberi perhatian dalam merancang keberkesanan Proses Pengajaran dan pembelajaran dan kaedah penilaian bagi menilai keberkesanan Proses Pengajaran dan Pembelajaran serta kelebihan dan ke kurangannya. Penilaian Tahap Kecekapan Kementerian Pengajian Tinggi (Tahap Kecekapan 4) Siri $2 / 2010$.

[17] Hasan Langgulung. (1981).Beberapa Tinjauan Dalam Pendidikan Islam. Kuala Lumpur: Pustaka Antara.

[18] Institut Pendidikan Guru. (2011). Modul Bahasa Melayu BMM 3117-Kaedah Pengajaran Bahasa Melayu Sekolah
Rendah, Kementerian Pelajaran Malaysia.

[19] Kandil, Hisham Muhammad TakyEldin et al., (2007). USIM Merintis Kejayaan (Pioneering Success). Bandar Baru Nilai: Penerbit USIM.

[20] Kolej Universiti Islam Malaysia. (2005). BukuPanduan 2005/2006 Pusat Tamhidi KolejUniversiti Islam Malaysia. Bandar BaruNilai :Penerbit USIM.

[21] Mok Soon Seng. (1992). Pedagogi 2: Strategi Pengajaran Pembelajaran Mikro. Kuala Lumpur: Kumpulan Budiman.

[22] Muhamad SuhaimiTaat et al. (2012). Pengajaran dan penyampaian yang berkesan. UtusanBorneo .B4.

[23] Muhammad, Azharet al. (2012). Kemahiran bertutur dalam pengajaran dan pembelajaran Bahasa Arab. In: Seminar Antarabangsa Perguruandan Pendidikan Islam [SEAPPI2012] (International Seminar on Teacher and Islamic Education [SEAPPI2012]), 8-9 March 2012, Le Grandeur Palm Resort, Senai, Johor Bahru.

[24] Sharifah Alwitah Alsagoff. (1986). Ilmu Pendidikan: Pedagogi . Kuala Lumpur: Heineman Asia.

[25] Tamhidi Centre, Universiti Sains Islam Malaysia. (2013). Course Outline.

[26] Tamhidi Centre, Universiti Sains Islam Malaysia. http://tamhidi.usim.edu.my/. 25 October 2014.

[27] Universiti Sains Islam Malaysia. (2012). Program Tamhidi: Program Pengajian dan Syarat Kemasukan

[28] (Tamhidi Programs and Admission Requirements). 